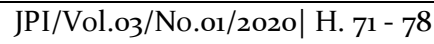

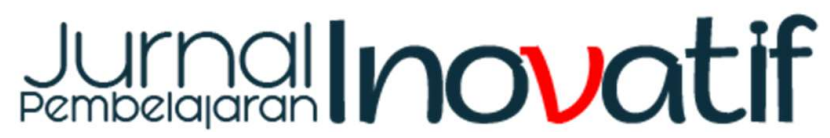

http://journal.unj.ac.id/unj/index.php/ipi

\section{Model Pembelajaran Magang Kognitif dan Gender Terhadap Hasil Karya Lukis}

\author{
Zaitun Y.A. Kherid, $₫$ \\ ${ }^{1}$ Universitas Negeri Jakarta, Indonesia \\ DOI: https://doi.org/10.21009/JPI.031.09
}

\begin{tabular}{l}
\hline Article History \\
\hline Submitted: 2019 \\
Accepted : 2020 \\
Published : 2020 \\
\hline
\end{tabular}

\section{Keywords}

Model Pembelajaran; Magang Kognitif; Gender; Karya Lukis

\begin{abstract}
Abstrak
Penelitian ini bertujuan untuk mengetahui pengaruh magang kognitif terhadap penciptaan hasil karya lukis mahasiswa dalam mata kuliah Seminar Penciptaan Tugas Akhir (SPTA). Penelitian ini merupakan penelitian eksperimen. Metodologi penelitian yang digunakan menggunakan metode kuasi eksperimen (quasi experiment) desain faktorial 2x2. Magang terdiri magang tradisional dan magang kognitif. Dalam prosedur magang tradisional pemagang melakukan segala sesuatu berdasarkan prosedur dan aturan main yang berlaku di tempat magang dan menciptakan karya berdasarkan arahan dari narasumber, sedangkan prosedur dalam magang kognitif lebih menitikberatkan pada membangun proses berpikir pemagang di dalam memahami, menciptakan dan mengatasi persoalan berpikir dalam proses penciptaan karya. Penelitian ini mengungkapkan bahwa model magang dan jenis kelamin secara signifikan mempengaruhi varian hasil karya lukis dan terdapat interaksi antara model magang dengan jenis kelamin yang berperan bagi varian hasil karya lukis pada kuliah Seminar Penciptaan Tugas Akhir (SPTA).
\end{abstract}

\begin{abstract}
This study aims to determine the effect of cognitive apprenticeship on the creation of student paintings in the Final Project Creation Seminar (SPTA) course. This research is an experimental research. The research methodology used is a quasi-experimental method with a $2 \times 2$ factorial design. Internships consist of traditional apprenticeships and cognitive internships. In the traditional apprenticeship procedure the apprentice does everything based on the procedures and rules that apply in the apprenticeship and creates work based on the direction of the resource persons, while the procedure in cognitive apprenticeship focuses more on building the apprentice's thought process in understanding, creating and overcoming problems of thinking in the creation process creation. This study revealed that the apprenticeship model and gender significantly influenced the variant of the work of the painting and there was an interaction between the internship model and the sex that contributed to the variant of the work of painting in the Final Project Creation Seminar (SPTA) course.
\end{abstract}

${ }^{\square}$ Corresponding author : Zaitun Y.A. Kherid Adress: Prodi Pendidikan Seni Rupa Universitas Negeri Jakarta Jakata, Indonesia

E-mail : eza kherid@unj.ac.id / kherid.eza@gmail.com
(C) 2020 Universitas Negeri Jakarta 


\section{PENDAHULUAN}

Perguruan tinggi sebagai institusi pendidikan memiliki peran sangat besar dalam mempersiapkan sumber daya manusia yang berkualitas, dan sekaligus siap dalam menghadapi dunia kerja. Salah satu cara yang dilaksanakan perguruan tinggi adalah melalui model pembelajaran magang. Pelaksanaan magang telah diatur pada Peraturan Pemerintah Nomor 17 Tahun 2010 tentang Pengelolaan dan Penyelenggaraan Pendidikan, pasal 90 ayat (g) Pemagangan. Universitas Negeri Jakarta merupakan salah satu perguruan tinggi yang menyelenggarakan program magang dalam kurikulumnya. Magang dalam mata kuliah Seminar Penciptaan Tugas Akhir (SPTA) di Program Studi Pendidikan Seni Rupa merupakan pengenalan suasana dalam dunia profesional yang akan dihadapi oleh mahasiswa sehingga dapat siap pakai dan siap terjun di dunia kerja setelah menyelesaikan studi dan dapat membuka cakrawala kreativitasnya.

Magang terdiri dari dua jenis yaitu magang tradisional dan magang kognitif. Dalam prosedur magang tradisional pemagang melakukan segala sesuatu berdasarkan prosedur dan aturan main yang berlaku di tempat magang dan menciptakan karya berdasarkan arahan dari narasumber, sedangkan dalam magang kognitif prosedur magang lebih menitikberatkan pada membangun proses berpikir pemagang di dalam memahami, menciptakan dan mengatasi persoalan berpikir dalam proses penciptaan karya.

Pada hakikatnya dalam pengertian magang terkandung dengan jelas adanya perencanaan, pengelolaan dan evaluasi sumbersumber belajar yang meliputi antara lain: narasumber, perencanaan dan prosedur kegiatan, berbagai peralatan dan sistem penggunaannnya, yang kesemuanya dikelola dengan tujuan untuk meningkatkan produktivitas, kemandirian, efisiensi dan efektivitas, serta perluasan proses belajar. Unsur-unsur dan tujuan dalam kegiatan magang tersebut sangat sesuai dengan formulasi pengertian teknologi pendidikan.

Yusufhadi Miarso (2004, h.6) mengemukakan bahwa teknologi pendidikan merupakan suatu proses yang komplek dan terintegrasi meliputi manusia, alat, dan sistem, termasuk diantaranya gagasan, prosedur, dan organisasi, serta memakai pendekatan yang sistematis dalam rangka menganalisa dan memecahkan persoalan proses belajar.

Berdasarkan latar belakang dan masalah tersebut maka dapat dirumuskan 7 masalah sebagai berikut: (1) apakah terdapat perbedaan hasil karya lukis mata kuliah Seminar Persiapan Tugas Akhir (SPTA) antara mahasiswa yang menggunakan model magang kognitif (cognitive appe-renticeship) dengan model magang tradisional (traditional apperenticship)? (2) apakah ter-dapat perbedaan hasil karya lukis mata kuliah Seminar Persiapan Tugas Akhir (SPTA) antara mahasiswa laki-laki dengan mahasiswa perempuan? (3) apakah terdapat pengaruh interaksi antara model magang dan jenis kelamin terhadap hasil karya mata kuliah Seminar Persiapan Tugas Akhir (SPTA)? (4) apakah terdapat perbedaan hasil karya lukis mata kuliah Seminar Persiapan Tugas Akhir (SPTA) mahasiswa laki-laki yang magang menggunakan model magang kognitif dengan hasil karya mahasiswa laki-laki yang menggunakan model magang tradisional? (5) apakah terdapat perbedaan hasil karya lukis mata kuliah Seminar Persiapan Tugas Akhir (SPTA) antara mahasiswa perempuan yang magang menggunakan model magang kognitif dengan hasil karya mahasiswa perempuan menggunakan model magang tradisional? (6) apakah terdapat perbedaan hasil karya lukis mata kuliah Seminar Persiapan Tugas Akhir (SPTA) antara mahasiswa laki-laki dengan mahasiswa perempuan yang magang menggunakan model magang kognitif? (7) apakah terdapat perbedaan hasil karya lukis pada mata kuliah Seminar Persiapan Tugas Akhir (SPTA) antara mahasiswa laki-laki dengan mahasiswa perempuan yang magang menggunakan model magang tradisional?

\section{Teori Belajar}

Belajar (learning) menurut dalam Theories of Learning American Heritage Dictionary mendefinisikan belajar "To gain knowledge, comprehension, or mastery through experience or study" yang artinya untuk mendapatkan pengetahuan, pemahaman, atau penguasaan melalui pengalaman atau studi (B.R. Hergenhahn dan Matthew H. Olson, 2008, h.4). Thorndike mengatakan bahwa "kekuatan 
manusia untuk mengubah dirinya sendiri, yakni untuk belajar, mungkin merupakan aspek yang paling mengesankan dari diri manusia”. (Gredler, Margaret. E, 2011, h.2). Sedangkan menurut Skinner belajar didefinisikan sebagai modifikasi atau penguatan perilaku melalui pengalaman "learning is defined as the modification or strengthening of behavior through experience", (B.R. Hergenhahn and Matthew H. Olson, Ibid, h.4).

Belajar bukan sekedar berubah dari belum atau tidak tahu menjadi tahu, dan bukan juga sekedar perubahan perilaku sementara, melainkan perubahan perilaku yang menetap, yang dinamakan kebiasaan baru. Alan Januszewsi dan Molenda (2008, h18) kebiasaan baru ini kelak akan menjadi kebiasaan lama yang dinamakan zona nyaman. Agar tumbuh dan berkembang, maka perlu belajar dan itu berarti membongkar zona nyaman ini menuju kebiasaan baru. Berikutnya ini AECT menggambarkan skema proses belajar seperti di bawah ini:

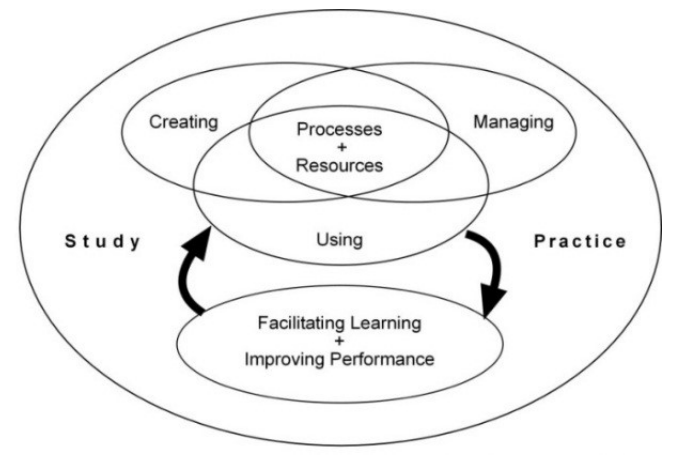

A visual summary of key elements of the current learning definition from AECT

Gambar 1

Proses pembelajaran menurut AECT

Berdasarkan skema di atas merupakan gambaran kunci keberhasilan hasil belajar yang dikemukakan oleh AECT adalah tujuan pembelajaran dapat mencakup dari beberapa faktor di antaranya belajar dan mempraktekannya, di dalam proses belajar peserta didik akan mendapatkan keberhasilan proses pembelajaran secara satu kesatuan dengan pemberi fasilitas (dalam hal ini kampus), serta melakukan penerapan hasil belajar yang telah di dapatkannya. Berbagai perubahan yang terjadi merupakan serangkaian proses pembelajaran yang memberikan output maupun outcome sebagai hasil pem-belajaran yang bersifat jangka panjang.
Menurut Sardiman (1992, h. 99-101) beberapa aktivitas yang dilakukan oleh peserta didik dalam proses belajar dapat dirangkum dalam delapan tahapan diantaranya sebagai berikut: visual activities, oral activities, listening activities, writing activities, drawing activities, motor activities, mental activities, emotional activities. Berdasarkan pandangan para ahli dan kedelapan aspek di atas dapat disimpulkan bahwa belajar secara umum diartikan sebagai perubahan perilaku tetap dari belum tahu menjadi tahu, dari tidak paham menjadi paham, dari kurang terampil menjadi terampil, dan dari kebiasaan lama menjadi kebiasaan baru, serta bermanfaat bagi lingkungan maupun individu itu sendiri.

Belajar yang dilakukan oleh mahasiswa dalam pembelajaran ini merupakan pembelajaran yang berorientasi pada hasil karya, yang dilakukan melalui model pembelajaran luar sekolah atau nonformal dengan cara pemagangan (apprenticeship). Penciptaan karya lukis merupakan hasil belajar yang dibahas dalam penelitian ini.

\section{Penciptaan Karya Seni Lukis}

Deskripsi mata kuliah seminar penciptaan karya seni rupa mencakup pengetahuan, keterampilan dan kepekaan dalam penyusunan konsep penciptaan dan visualisasi salah satu cabang seni rupa melalui pengalaman magang dalam dunia kesenirupaan, (Pedoman Akademik Universitas Negeri Jakarta 2013, h.289). Seni dalam pengertiannya yang paling universal selalu diidentifikasikan sebagai sebuah keindahan karena keindahan di sini merupakan unsur yang sangat penting dalam seni. Herbet Read (1959, h.17) menyebutkan bahwa seni merupakan usaha manusia untuk menciptakan bentuk-bentuk yang menyenangkan. Bentuk yang menyenangkan disini diartikan sebagai sebagai bentuk yang dapat membingkai perasaan keindahan. Lebih lanjut Suzanne K. Langer (1974, h.3), seorang filsuf Amerika, mengatakan seni merupakan bentuk simbolis dari perasaan manusia, bentuk-bentuk simbolis yang mengalami tranformasi yang merupakan universalisasi dari sebuah pengalaman atau bukan sekedar terjemahan dari sebuah pengalaman tertentu.

Unsur-unsur rupa dan prinsip-prinsip penataan merupakan aspek dasar yang wajib dalam membuat karya seni lukis. Dalam lukisan terkandung 6 unsur utama, yaitu titik, garis, 
bidang, bentuk, warna, tekstur. Al Hurwitz and Michael Day James Hall, (2007, hh. 185-189) mengungkapkan bahwa unsur-unsur rupa harus diatur menggunakan prinsip-prinsip penataan yang terdiri dari: kesatuan (unity), keseimbangan (balance), irama (rhytm), proporsi (proportion), penekanan (emphasis), dan keselarasan (harmony).

\section{Pemagangan (Apprenticeship)}

Kata magang sebagai istilah dalam bahasa Inggris dikenal sebagai internship/ apprenticeship/ on the job training. Definisinya adalah "an opportunity to integrate career related experience into an undergraduate education by participating in planned, supe-rvised work". Magang tradisional merupakan jenis magang yang telah diketahui oleh masyarakat secara umum. Adapun magang kognitif adalah suatu model desain instruksional yang didasarkan pada pemahaman tentang cara-cara individu belajar dalam dunia nyata. Istilah ini pertama kali diciptakan dan diartikulasikan oleh Collins, Brown, dan Newman, bahwa:

"We propose an alternative model of instruction that is accessible within the framework of the typical American classroom. It is a model of instruction that goes back to apprenticeship but incorporates elements of schooling. We call this model "cognitive apprenticeship".

Jean Lave dalam Dennen, Vanessa Paz (2004, hh.814-817) mengungkapkan magang kognitif lebih menekankan pada enam aspek yaitu; modelling (pemodelan) coaching (pembinaan), scaffolding (perancah/ bantuan), articulation (artikulasi), reflection (merefleksikan), dan exploration (eksplorasi),

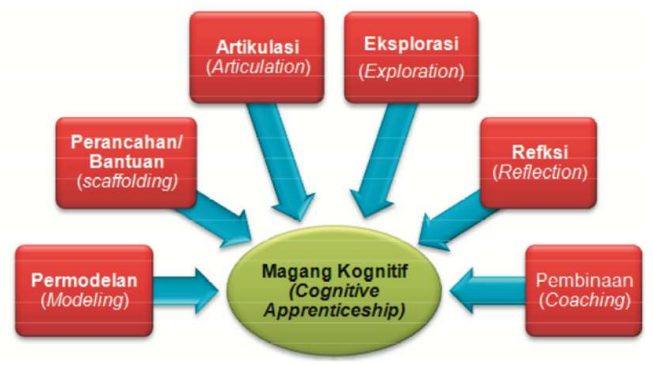

Gambar 2

Skema sistematika proses pembelajaran model magang kognitif.

\section{Penilaian Karya Seni Lukis}

Pada umumnya penilaian diartikan sebagai aktivitas pengukuran hasil belajar berdasarkan acuan tertentu. Dalam Peraturan Pemerintah No 19 tahun 2005 disebutkan bahwa penilaian pendidikan adalah proses pengumpulan dan pengolahan informasi untuk menentukan pencapaian hasil belajar peserta didik. Adapun penilaian pendidikan seni ditujukan untuk menilai hasil belajar peserta didik secara menyeluruh, men-cakup aspek kognitif, afektif, dan psikomotorik. Hal ini sesuai dengan pernyataan Gaitskell dalam (Elliot W Eisner, 2002, hh. 6-10) sebagai berikut:

Behaviorists in art education also recommend that the three major domains of learning be maintained. These domains, or classifications of learning cog-nititive (knowledge, fact, intellecttual abilities), affective (feelings and attitudes), and psychomotor (ability to handle specific processes involving physical coordination) skills.

kegiatan magang kognitif ini lebih ditekankan pada aspek kognitif dan psikomotor, yang peneliti kaji berdasarkan evaluasi penilain karya seni menurut Brent G. Wilson dalam aspek produksi. Aspek produksi di dalam penilaian Brent G. Wilson (1971, hh.502-503) terdiri dari dua sub aspek, yaitu keterampilan dan kreativitas. Selain itu Wilson menetapkan muatan seni yang terdiri dari: penguasaan media, alat dan bahan, proses pembentukan, struktur visual, dan subjek matter, sebagaimana tampak pada table berikut ini:

Tabel 1

Tabel penilaian untuk pendidikan seni Brent $\mathrm{G}$ Wilson.

\begin{tabular}{|c|c|c|}
\hline No & Muatan Seni & $\begin{array}{l}\text { Produksi (keterampilan } \\
\text { dan kreativitas) }\end{array}$ \\
\hline 1. & $\begin{array}{l}\text { Media, tools, } \\
\text { and forming } \\
\text { processes. }\end{array}$ & $\begin{array}{l}\text { Dalam kolom ini dinilai } \\
\text { tingkat keterampilan dan } \\
\text { kreativitas aspek Media, } \\
\text { tools, and forming } \\
\text { processes dalam karya } \\
\text { lukis. }\end{array}$ \\
\hline 2. & $\begin{array}{l}\text { Visual } \\
\text { structures } \\
\text { (struktur } \\
\text { visual) yang } \\
\text { terdiri dari } \\
\text { kualitas } \\
\text { sensori, } \\
\text { komposisi dan } \\
\text { karakter rupa. }\end{array}$ & $\begin{array}{l}\text { Dalam kolom ini dinilai } \\
\text { tingkat keterampilan dan } \\
\text { kreativitas aspek Struktur } \\
\text { Visual yang terdiri dari } \\
\text { kualitas sensori, komposisi } \\
\text { dan ciri khas terlihat } \\
\text { dalam karya. }\end{array}$ \\
\hline 3. & $\begin{array}{l}\text { Subject matter, } \\
\text { objek }\end{array}$ & $\begin{array}{l}\text { Dalam kolom ini dinilai } \\
\text { tingkat keterampilan dan } \\
\text { kreativitas aspek Subject }\end{array}$ \\
\hline
\end{tabular}




\begin{tabular}{ll}
\hline peristiwa/ & $\begin{array}{l}\text { matter, objek peristiwa/ } \\
\text { tema terlihat dalam karya } \\
\text { lukis. }\end{array}$ \\
\hline
\end{tabular}

Berdasarkan tabel penilaian Brent G. Wilson tersebutlah yang digunakan dalam menilai hasil karya lukis pada mata kuliah SPTA yang telah selesai dibuat oleh mahasiswa setelah menjalankan proses magang.

\section{Jenis Kelamin dalam Karya Seni}

Sejarah perbedaan jenis kelamin antara laki-laki dan perempuan terjadi melalui proses yang sangat panjang, melalui proses sosial, kultur, keagamaan bahkan kekuasaan Negara. Selain itu juga adanya perbedaan otak kanan dan kiri yang mejadi sumber dari semua organ manusia. Whiteson seperti dikutip Bahaudin menyatakan bahwa anak laki-laki lebih cepat dalam perkembangan spesialisasi otak kanan bila dibandingkan anak perempuan. Anak lakilaki menunjukkan kemampuan lebih baik dari anak perempuan dalam kaitannya dengan kemampuan spasial, sedangkan anak perempuan lebih cepat menguasai bahasa dibanding dengan anak laki-laki (Taufik Bahaudin, 200o, h.81).

Jaringan yang menghubungkan otak kanan dan otak kiri (Corpus callosum) anak perempuan lebih besar, lebih tebal dan lebih berat bila dibandingkan dengan anak laki-laki. Belahan kiri cerebal cortex anak perempuan lebih tebal dan kepadatan sel-selnya lebih rendah serta fungsi hypothalamusnya membuat emosinya lebih tinggi dibanding anak laki-laki. Pada umumnya anak perempuan lebih cepat berbicara, belajar bahasa dan membaca bila dibandingkan anak laki-laki. (Gordun Dryden and Jeannette, 200o, h.299).

Hasil tes Stanford Bineet menunjukkan bahwa laki-laki memiliki kemampuan lebih baik dalam bidang matematik, mekanika dan aktivitas yang tidak memerlukan alasan logis. (Hilary M. Lips, 2014, hh.2-6) Ada-pun Dembo mengemukakan bahwa laki-laki bersifat agresif, bebas, bersaing dan berpetualang, laki-laki lebih unggul pada pembelajaran yang membutuhkan berbagai penalaran dan keterampilan ruang, (Myron H. Dembo, 1981, h.129) - Selain itu Hughes (1982, h.129) mengungkapkan bahwa laki-laki unggul dalam pembelajaran yang memerlukan berbagai penalaran dan berbagai keterampilan ruang. Pendapat tersebut ditunjang oleh Thurstone yang dikutip oleh Hughes bahwa laki-laki dapat berfikir secara independen, analitikal, ilmiah dan tidak tertarik pada sistematika yang kaku. Ausubel dan Robinson mengemukakan bahwa kemampuan mental utama pada laki-laki lebih superior dalam spatial (ruang) dan keterampilan kuantitatif (menghitung).

Hasil tes Stanford Binet seperti dikutip Gilley dan Gilley (1980, hh.72-73) menunjukkan bahwa perempuan memiliki kemampuan lebiih baik dalam tugas-tugas yang berhubungan dengan membaca, estetika, keterampilan dan sosial. Adapun Parsons seperti dikutip oleh Gerungan mengemukakan bahwa wanita berkelebihan dalam hal mengerjakan tes-tes yang menyangkut penggunaan bahasa, hapalan, reaksi-reaksi estetika serta masalah-masalah sosial. Garry menyatakan bahwa pada pengukuran kelancaran berbicara, perempuan biasanya lebih unggul dari pada laki-laki. Perempuan berbicara lebih awal daripada lakilaki dalam menggunakan kalimat dan mempraktekkan variasi kata-kata yang lebih banyak.

Perbandingan kemampuan antara anak laki-laki dan anak perempuan berdasarkan teori yang telah dikemukakan dapat dijabarkan secara singkat sebagai berikut: (John Archer, and Barbara B. Lloyd, 2002, hh.8-12)

Tabel 2.2

Perbandingan kemampuan anak laki-laki dengan anak perempuan

\begin{tabular}{|c|c|c|}
\hline No & Anak Laki-Laki & Anak Perempuan \\
\hline 1. & $\begin{array}{l}\text { Lebih baik dalam } \\
\text { kemampuan } \\
\text { matematika }\end{array}$ & $\begin{array}{l}\text { Lebih baik dalam } \\
\text { kemampuan } \\
\text { membaca }\end{array}$ \\
\hline 2. & $\begin{array}{l}\text { Penguasaan } \\
\text { mekanikal }\end{array}$ & $\begin{array}{l}\text { Penguasaan bahasa } \\
\text { asing }\end{array}$ \\
\hline 3. & $\begin{array}{l}\text { Lebih baik dalam } \\
\text { pola penglihatan, } \\
\text { hubungan abstrak }\end{array}$ & $\begin{array}{l}\text { Mendengar lebih } \\
\text { tajam }\end{array}$ \\
\hline 4. & $\begin{array}{l}\text { Kemampuan } \\
\text { spatial }\end{array}$ & Kemampuan verbal \\
\hline 5. & $\begin{array}{l}\text { Lebih baik dalam } \\
\text { teori dari sesuatu } \\
\text { yang nyata }\end{array}$ & $\begin{array}{l}\text { Unggul dalam } \\
\text { intuisi dan } \\
\text { perasaan }\end{array}$ \\
\hline 6. & $\begin{array}{l}\text { Pertanyaan lebih } \\
\text { menyelidik }\end{array}$ & $\begin{array}{l}\text { Pertanyaan lebih } \\
\text { keingintahuan }\end{array}$ \\
\hline $7 \cdot$ & Lebih analitis & Lebih kontekstual \\
\hline 8. & $\begin{array}{l}\text { Melihat sesuatu } \\
\text { lebih linear }\end{array}$ & $\begin{array}{l}\text { Melihat sesuatu } \\
\text { lebih holistik/ } \\
\text { global }\end{array}$ \\
\hline 9. & $\begin{array}{l}\text { Lebih baik dalam } \\
\text { mengatasi masalah }\end{array}$ & $\begin{array}{l}\text { Lebih baik dalam } \\
\text { memahami } \\
\text { masalah }\end{array}$ \\
\hline
\end{tabular}


Zaitun Y.A. Kherid | JPI/Vol.o3/No.01/2020| H. $71-78$

\begin{tabular}{cll}
\hline 10. & $\begin{array}{l}\text { Lebih memahami } \\
\text { fakta }\end{array}$ & $\begin{array}{l}\text { Lebih memahami } \\
\text { proses }\end{array}$ \\
11. & $\begin{array}{l}\text { Membentuk } \\
\text { kelompok tugas }\end{array}$ & $\begin{array}{l}\text { Membentuk } \\
\text { kelompok }\end{array}$ \\
12. & $\begin{array}{l}\text { Pendekatan untuk } \\
\text { kreativitas lebih }\end{array}$ & $\begin{array}{l}\text { Pendekatan untuk } \\
\text { kreativitas lebih }\end{array}$ \\
& teknis, perangkat & intuitif dan \\
& keras dan & relasional \\
& berorientasi pada & \\
& sesuatu & \\
\hline
\end{tabular}

\section{METODE}

Metode dalam penelitian ini menggunakan metode kuasi eksperimen (quasi experiment). Analisis data terdiri atas analisis deskriptif dan inferensial. Sebelum melakukan analisis, terlebih dahulu dilakukan uji prasyarat yang mencakup uji normalitas dan homogenitas data. Uji normalitas data dimaksudkan untuk menguji data hasil belajar yang diperoleh berasal dari data populasi yang berdistribusi normal atau tidak. Untuk pengujian normalitas menggunakan Uji Liliefors, sedangkan Uji Homogenitas data menggunakan Uji Bartlett.

Desain penelitian ini menggunakan desain faktorial 2 x 2, maka jalur analisis datanya menggunakan analisis varians (ANAVA) dua jalur. Apabila interaksi antara model magang dan jenis kelamin menunjukan hasil yang signifikan, maka dilanjutkan dengan menguji simple effect A pada level $\mathrm{B}_{1}$ dan $\mathrm{B}_{2}$ dengan Uji Tukey untuk melihat perbedaan kelompok $A_{1} B_{1}$ dan $A_{2} B_{2}$ serta perbedaan kelompok $A_{1} B_{2}$ dan $\mathrm{A}_{2} \mathrm{~B}_{2}$.

\section{HASIL DAN PEMBAHASAN}

Data hasil penelitian berupa hasil karya lukis mata kuliah Seminar Persiapan Tugas Akhir (SPTA) mahasiswa (Y) sebagai akibat dari perlakuan penelitian $\left(\mathrm{X}_{1}\right)$, yaitu Model Magang (A), berupa Magang Kognitif $\left(\mathrm{A}_{1}\right)$ dan Magang Tradisional $\left(\mathrm{A}_{2}\right)$, serta jenis kelamin $(\mathrm{B})$, yang dibedakan atas jenis kelamin laki-laki $\left(B_{1}\right)$ dan Perempuan $\left(\mathrm{B}_{2}\right)$. Data hasil penelitian dianalisis dengan teknik statistik deskriptif dan perhitungan data hasil penelitian dilakukan dengan menggunakan program "microsoft excel".

Dari data awal pada penelitian ini, diperoleh data tertinggi adalah 92 dan data terendah sebesar 58 , dengan mean sebesar 77,08 dan data media sebesar 81,25 serta serta modus sebesar 83.33. Selain dari pemusatan data tersebut, diperoleh pula standar deviasi sebesar 10,92. Penelitian ini mengungkapkan bahwa model magang dan jenis kelamin secara signifikan mempengaruhi varians hasil karya lukis pada mata kuliah Seminar ] iptaan Tugas Akhir (SPTA), dan terdapat interaksi antara model magang dengan jenis kelamin yang berperan bagi varians hasil karya lukis pada mata kuliah Seminar Penciptaan Tugas Akhir (SPTA). Dilihat dari penelitian ini, tampak perbedan yang sangat dominan antara model magang kognitif dengan model magang tradisional. Dalam model pembelajaran magang kognitif, penekanan proses pembuatan karya lukis Magang kognitif memiliki prosedur magang yang lebih menitikberatkan pada membangun proses berpikir pemagang di dalam memahami, menciptakan dan mengatasi persoalan berpikir. Penelitian ini mengungkapkan bahwa model magang dan jenis kelamin secara signifikan mempengaruhi varians hasil karya lukis pada mata kuliah Seminar Penciptaan Tugas Akhir (SPTA) di Jurusan Seni Rupa Fakultas Bahasa dan Seni Universitas Negeri Jakarta. Dan terdapat interaksi antara model magang dengan jenis kelamin yang berperan bagi varians hasil karya lukis pada mata kuliah Seminar Penciptaan Tugas Akhir (SPTA).

Dilihat dari penelitian ini, tampak perbedan yang sangat dominan antara model magang kognitif dengan model magang tradisional. Dalam model pembelajaran magang kognitif, penekanan proses pembuatan karya lukis mahasiswa dibentuk dengan cara diskusi (brainstorming) berdasarkan permasalahan atau sumber ide yang ingin ditorehkan ke dalam karya dengan narasumber menggunakan enam tahapan magang kognitif yang dikem-bangkan oleh Collins yakni, modelling (pemodelan), coaching (pembinaan), scaffolding (perancah/bantuan), articulation (arti-kulasi), reflection (merefleksikan), dan exploration (eksplorasi). Magang kognitif memiliki prosedur magang yang lebih menitik-beratkan pada membangun proses berpikir pemagang di dalam memahami, menciptakan dan mengatasi persoalan berpikir. Mahasiswa laki-laki lebih menyukai cara kerja yang di bangun melalui pemecahan masalah, sehingga karya yang diciptakan merupakan asimilasi berdasarkan ide hasil brainstorming dengan narasumber. Sesuai dengan psikologi laki laki yang menyukai 
tantangan serta mengedepankan logika dari pada perasaan kegiatan magang seperti ini menarik untuk dilakukan.

Namun berbeda dengan mahasiswa perempuan yang lebih dominan dalam model magang tradisional, kecenderungan sifat perempuan yang lebih mahir dalam bahasa, sensory awareness, memori, kesadaran sosial dan hubungan dengan pihak lain. Kecenderungan psikologi perempuan yang lebih tidak menyukai tantangan tentunya prosedur magang tradisional tersebut lebih menyenangkan dikerjakan. Sebaliknya untuk magang kognitif, dengan prosedur magang yang lebih menitikberatkan pada membangun proses berpikir pemagang di dalam memahami, menciptakan dan mengatasi persoalan berpikir. Kecenderungan psikologi perem-puan tersebut membuat beberapa perempuan kesulitan pada saat dibebaskan berekspresi, dikarenakan perempuan kurang menyukai tantangan dan lebih menyukai hal yang pasti.

\section{SIMPULAN}

Berdasarkan proses dan hasil pengolahan data, dapat dirumuskan sejumlah kesimpulan sebagai berikut: 1) Hasil karya lukis mata kuliah Seminar Persiapan Tugas Akhir (SPTA) yang mengguna-kan model magang kognitif (cognitive apperenticeship) lebih baik dengan hasil karya yang menggunakan model magang tradisional (traditional apperenticship), 2) Hasil karya lukis mata kuliah Seminar Persiapan Tugas Akhir (SPTA) antara mahasiswa laki-laki dengan mahasiswa perempuan tidak terlalu mengalami perbedaan yang signifikan, 3) Terdapat pengaruh Interaksi antara model magang dan jenis kelamin terhadap hasil karya lukis mata kuliah Seminar Persiapan Tugas Akhir (SPTA), 4) Hasil karya lukis mata kuliah Seminar Persiapan Tugas Akhir (SPTA) mahasiswa laki-laki yang menggunakan model magang kognitif lebih baik dengan hasil karya mahasiswa laki-laki yang menggunakan model magang tradisional, 5) Hasil karya lukis mata kuliah Seminar Persiapan Tugas Akhir (SPTA) mahasiswa perempuan yang menggunakan model magang kognitif tidak lebih baik dengan hasil karya mahasiswa perempuan menggunakan model magang tradisional, 6) Hasil karya mata kuliah Seminar Persiapan Tugas Akhir (SPTA) antara mahasiswa laki-laki yang menggunakan model magang kognitif lebih baik dengan mahasiswa perempuan yang menggunakan model magang kognitif, 7) Hasil karya mata kuliah Seminar Persiapan Tugas Akhir (SPTA) antara mahasiswa laki-laki yang menggunakan model magang tradisional tidak lebih baik dengan mahasiswa perempuan yang menggunakan model magang tradisional.

Saran dari penelitian ini diharapkan dapat menjadi bahan acuan dan masukan keilmuan bagi Teknologi Pendidikan agar model pembelajaran magang kognitif merupakan salah satu alternatif model pembelajaran magang yang tidak hanya menitikberatkan dalam aspek kognitif, melainkan mem-bangun pola berpikir dalam pemecahan masalah yang dikembangkan mahasiswa untuk menciptakan karya seni. Jurusan Seni Rupa, dan narasumber tempat magang. Bagi Jurusan Seni Rupa Pola pembelajaran magang kognitif dapat diadaptasi untuk jenis mata kuliah lainnya yang melibatkan narasumber ahli dalam beberapa pertemuan proses pembelajaran. Dan terakhir bagi narasumber tempat magang agar bersedia bekerjasama dengan Jurusan Seni Rupa menggunakan instrumen model magang kognitif selama proses bimbingan kepada mahasiswa.

\section{UCAPAN TERIMA KASIH}

Ucapan terima kasih kepada seluruh pihak yang telah membantu dalam proses penelitian ini. Terima kasih yang tak terhingga kepada Prof. Dr. Yufiarti, M.Psi. selaku dosen pembimbing 1 dan Prof. Dr. Hartati Muchtar, M.Pd. dosen pembimbing 2 yang memberikan bimbingan serta arahannya dalam penyelesaian penelitian ini.

\section{DAFTAR PUSTAKA}

Al Hurwitz and Michael Day James Hall. Children and Their Art: Methods for the Elementary School, Eighth Edition. Belmont: Thomson Wadsworth. 2007.

Archer, John and Barbara B. Lloyd. Sex and Gender. Second Edition. New York: Cambridge University Press. 2002.

Baharudin, Taufik. Brain Ware Management: Generasi Kelima Manajemen Manusia. Jakarta: Elex Media Komputindo. 2000. 
BNSP, PP Nomor 19 Tahun 2005, Tentang Standar Nasional Pendidikan. Jakarta. 2006.

Collingwood, R.G. The Principles of Art. New York: Oxford University Press. 1974.

Dembo, Myron H. Teaching for Learning. Santa Monica: Goodyear Publishing Co. 1981.

Dennen, Vanessa Paz. Cognitive Apperenticeship in Educational Practice: Research on scaffolding, Modeling, Mentoring, and Coaching as instructional strategies, Edited by David $\mathrm{H}$ Jonassen, On Handbook of Research on Educational Communications and Technology. Second Edition. New Jersey: Lawrence Erlbaum Acs. 2004.

Dryden, Gordun and Jeannette Vos. Revolusi Cara Belajar: Belajar Akan Lebih Efektif Kalau Anda dalam Keadaan Fun. Bandung: Kaifa, 2000.

Eisner, Elliot W. The Art and the Creation of Mind. London: Yale University Press. 2002.

Eisenberg, Nancy. Handbook of Child Psychology. Vol 3 Sosial, Emotional, and Personality Development. Canada: John Wiley \& Sons, Inc., 2006.

Gilley, Jean Mack and B.H Gilley. Early Chilhood Development and Education. New York: Delmar Publishing Inc, 1980.

Gredler, Margaret. E. Learning and instruction, teori dan aplikasi. Jakarta: Kencana, 2011.

Hergenhahn B.R., dan Matthew H. Olson. Theories of Learning. Jakarta: Kencana. 2008

Hughes, J. M. Education in America.New York: Harper \& Row Publisher, 1982.

Januszewsi, Alan dan Molenda, Educational Technology A Definition with Commentary. New Jersey: Taylor \& Francis Group, LLC, 2008.

Kemenade dan Garre. Total Quality Management, Prosiding Seminar Nasional Pendidikan Teknik Mesin FT UNY, Sabtu, 2 Juni 2012, hh. 4951.http://staff.uny.ac.id/sites/default/files /penelitian/dr-dwi-rahdiyanta-mpd/7penerapan-total-quality-managementeducation-tqme.pdf (diakses 12 Mei 2014)

Lave, Jean. Situating Learning in Communities of Practice. Urbana Champaign: University of Illinois, 2007.

Lips, Hilary M. Gender the Basics. New York: Routledge, 2014.
Miarso, Yusufhadi. Menyemai Benih Teknologi Pendidikan. Jakarta; Kencana. September, 2004.

Pedoman Akademik Universitas Negeri Jakarta. Jakarta: UNJ, 2012/2013.

Read, Herbert. The Meaning of Art, New York: Pinguin Book, 1959, h. 17.

Sardiman. A.M, Interaksi dan Motivasi Belajar Mengajar. Jakarta: Raja Grasindo Persada, 1992.

Tim Penyusun, Pedoman Tugas Akhir Penciptaan Karya Seni Rupa, Jakarta: Jurusan Seni Rupa UNJ, 2010.

Wilson, Brent G. "Evaluation of Learning in Art Education”, dalam Benjamin S Bloom, dkk, Handbook on Formative and Summative Evaluation of Student Learning. New York: McGraw-Hill Book Company. 1971.

Witherington, H.C. Psikologi Pendidikan. Terjemahan M. Buchari. Jakarta: Aksara Baru, 1982. 